patients remain anxious until hypnotics, sedatives, tranquillisers, or narcotics are administered for premedication; even then, such treatment may be ineffective.

Egbert et al $^{1}$ " suggestect that patients who had received information during a reassuring, personal visit coped better with preoperative and postoperative stresses and experienced less pain and required fewer analgesics postoperatively, thus implying that recovery was speedier. Cartwright, ${ }^{8}$ however, showed that the successful application of medical expertise depends partly on the patient's feelings about the hospital in which he is being treated and the medical personnel with whom he has contact.

Our findings showed that either the trend away from preoperative visiting by anaesthetists should be reversed or the reassurer's role should be assumed by someone else. In the USA this role is undertaken by the nurse anaesthetist, ${ }^{9}$ and perhaps in Britain it could be assumed by anaesthetic nurses, escort and recovery room nurses, or even operating theatre nurses, as advocated by Welsh and Richardson. ${ }^{10}$ Although we felt that the provision of a cheaper alternative such as the explanatory booklet was reasonable, our study showed that in its present form the booklet was not an adequate substitute for a personal visit even though it did significantly decrease state anxiety levels.

The problem is probably best resolved by using a booklet to provide basic information, and then following this with a visit from an anaesthetic nurse, who can provide more personal reassurance. This combination of both kinds of support is the one most likely to provide an effective reduction in preoperative anxiety.

\section{References}

${ }^{1}$ Egbert, L D, et al, Journal of the American Medical Association, 1963, $185,553$.

${ }^{2}$ Norris, W, and Baird, W L M, British fournal of Anaesthesia, 1967, 39, 503.

${ }^{3}$ Norris, W, British fournal of Anaesthesia, 1969, 41, 778.

${ }^{4}$ Ramsay, M A E, Anaesthesia, 1972, 27, 396.

5 Spielberger, C D, Gorsuch, R L, and Lushene, R E, STAI Manual for the State-Trait Anxiety Inventory ("Self-Evaluation Questionnaire"). Palo Alto, Consulting Psychologists Press, 1970.

${ }^{6}$ Office of Health Economics, Anaesthesia. London, OHE, 1976.

' Egbert, L D, Lamdin, S J, and Hackett, T P, Anesthesiology, 1967, 28, 246.

${ }^{8}$ Cartwright, A, Human Relations and Hospital Care. London, Routledge and Kegan Paul, 1964.

${ }^{9}$ Bunker, J P, The Anesthesiologist and the Surgeon. Edinburgh, Churchill, 1972.

1" Welsh, J, and Richardson, A, National Association of Theatre Nurses News, 1976, 13 (July), 12.

(Accepted 19 August 1977)

\title{
Association of polymyalgia rheumatica and giant-cell arteritis with HLA-B8
}

\author{
B HAZLEMAN, A GOLDSTONE, D VOAK
}

\section{Summary}

Histocompatibility antigens were determined in 30 patients with temporal arteritis, 27 patients with polymyalgia rheumatica, and 216 normal blood donors. HLA-B8 was significantly more common in patients with polymyalgia rheumatica $(59 \%)$ and temporal arteritis $(50 \%)$ than in the controls $(27 \%)$.

The findings of HLA-A10 in $26 \%$ of the patients with polymyalgia rheumatica compared with only $10 \%$ of the controls may be associated with the suggested immunological pathogenesis of the condition.

\section{Introduction}

There is an increasing tendency to regard giant-cell arteritis and polymyalgia rheumatica as being closely related. Giant-cell arteritis remains the only histological abnormality described in

Addenbrooke's Hospital, Cambridge CB2 $2 Q Q$

B HAZLEMAN, MB, MRCP, consultant rheumatologist

University College Hospital, London WC1E 6AU

A GOLDSTONE, MRCP, MRCPATH, consultant haematologist

Regional Transfusion and Immuno-Haematology Centre, Cambridge

D VOAK, PHD, MRCPATH, principal scientific officer polymyalgia rheumatica and widespread vasculitis would explain many of the features of the disease. Familial aggregation of polymyalgia rheumatica, and giant-cell arteritis has been reported by several workers, ${ }^{1-3}$ the relation between the two diseases recently being emphasised again by Liang et al. ${ }^{4}$ Four pairs of first-degree relatives with polymyalgia rheumatica or giant-cell arteritis or both were seen among 250 patients. Two of these pairs were mothers and daughters, and in three of the families the onset of the illness in the two members occurred within 12 months. Polymyalgia rheumatica and giant-cell arteritis are well recognised in England and Scandinavian countries, and in the USA most reports derive from Northern States, especially those with large populations of Scandinavian extraction. Black Americans seem to be rarely affected. ${ }^{j}$

Several recent observations have suggested a possible immunological basis for the disease. Immunoglobulin has been detected in the media of affected arteries ${ }^{6}$; infiltration of the internal elastic lamina by mononuclear cells ${ }^{7}$ has been reported; concentrations of circulating immunoglobulins, especially IgM, may be increased ${ }^{8}$; and increased sensitivity of peripheral blood lymphocytes to human artery and muscle has been found with a lymphocyte transformation test. ${ }^{9}$ We therefore decided to explore any possible association between histocompatibility antigens and polymyalgia rheumatica and giant-cell arteritis.

\section{Patients and methods}

Fifty-seven patients were studied ( 36 women and 21 men; mean age 62 years), 27 of whom had polymyalgia rheumatica, and 30 giantcell arteritis. Polymyalgia was diagnosed clinically, ${ }^{10} 11$ temporal artery biopsy being negative. The diagnosis of giant-cell arteritis was supported in all cases by a temporal artery biopsy. In no patient was rheumatoid factor or antinuclear antibody detected. 
HLA typing-Lymphocytes were separated from fresh blood samples treated with acid citrate dextrose by sedimentation over Ficoll and Triosil. Phagocytic mononuclear cells were removed by incubation with carbonyl iron and extraction with a magnet. Typing for HLA specificities was carried out on a Terasaki-type plate by a slight variation of the standard NIH microcytotoxicity technique. A $2 \mu \mathrm{l}$ sample of a lymphocyte suspension at a concentration of $1 \times 10^{\text {f }}$ cells $/ \mathrm{ml}$ was added to the test wells of the typing plates containing $2 \mu l$ of the known anti-HLA antisera and left at room temperature for 30 minutes. Then $4 \mu l$ of complement (three parts rabbit serum to one part human group AB serum) was added to each well. After incubation at room temperature for one hour, $1 \mu l$ trypan blue $(0.2 \%$ in isotonic saline) was added to each well, and then after 15 minute $1 \mu 11 \%$ bovine albumin followed by $1 \mu l 5 \%$ acetic acid were added and the plates read on an inverted microscope. Lymphocytes from the patients and from 216 symptom-free blood donors used as controls were tested for 22 antigens (see table I). Three antibody sera were used for the HLA specificities, including B27. Controls and patients were tested on at least two separate occasions.

Statistical significance was calculated by using the $\chi^{2}$ test alone and with Yates's correction. Corrected P values (Pc) were obtained by multiplying the $P$ value by 22 (number of specificities tested).

\section{Results}

A significant increase in the prevalence of HLA-B8 and HLA-A10 was detected (table I). B8 was found in $59(27 \%$ ) of the 216 controls but in $16(59 \%)$ of the 27 patients with polymyalgia rheumatica and $15(50 \%)$ of the 30 patients with temporal arteritis. Thus the overall prevalence of B8 in the 57 patients with these disorders was $54 \%$. A10 was present in $7(26 \%)$ of the patients with polymyalgia and $22(10 \%)$ of the controls. Significance values are given in table II. B8 was significantly increased in polymyalgia rheumatica, even after

TABLE I-HLA types in patients with temporal arteritis and polymyalgia rheumatica and controls (percentages given in parentheses)

\begin{tabular}{|c|c|c|c|c|}
\hline $\begin{array}{l}\text { HLA antigens } \\
(\mathrm{n}=22)\end{array}$ & $\begin{array}{l}\text { Patients with } \\
\text { temporal } \\
\text { arteritis } \\
(\mathrm{n}=30)\end{array}$ & $\begin{array}{l}\text { Patients with } \\
\text { polymyalgia } \\
\text { rheumatica } \\
\quad(n=27)\end{array}$ & $\underset{(\mathrm{n}=57)}{\text { All patients }}$ & $\begin{array}{l}\text { Controls } \\
(n=216)\end{array}$ \\
\hline \multicolumn{5}{|c|}{ First segregant series } \\
\hline $\begin{array}{l}\text { A1 } \\
\text { A2 } \\
\text { A3 } \\
\text { A9 } \\
\text { A10 } \\
\text { A11 } \\
\text { A29 } \\
\text { AW32 }\end{array}$ & $\begin{array}{l}13(43) \\
15(50) \\
7(23) \\
6(20) \\
4(13) \\
2(7) \\
0 \\
1(3)\end{array}$ & $\begin{aligned} 11(41) \\
14(52) \\
4(15) \\
5(19) \\
7(26) \\
3(11) \\
2(7) \\
0\end{aligned}$ & $\begin{array}{l}24(42) \\
29(51) \\
11(19) \\
11(19) \\
11(19) \\
5(9) \\
2(4) \\
1(2)\end{array}$ & $\begin{array}{r}84(39) \\
100(46) \\
53(25) \\
31(14) \\
22(10) \\
38(18) \\
6(3) \\
13(6)\end{array}$ \\
\hline \multicolumn{5}{|c|}{ Second segregant series } \\
\hline $\begin{array}{l}\text { B5 } \\
\text { B7 } \\
\text { B8 } \\
\text { B12 } \\
\text { B13 } \\
\text { B14 } \\
\text { BW17 } \\
\text { B27 } \\
\text { BW35 } \\
\text { BW40 } \\
\text { BW15 } \\
\text { B18 } \\
\text { BW22 } \\
\text { BW37 }\end{array}$ & $\begin{aligned} & 3(10) \\
& 5(17) \\
& 15(50) \\
& 7(23) \\
& 0 \\
& 1(3) \\
& 2(7) \\
& 2(7) \\
& 3(10) \\
& 1(3) \\
& 3(10) \\
& 0 \\
& 0 \\
& 0\end{aligned}$ & $\begin{aligned} & 1(4) \\
& 5(19) \\
& 16(59) \\
& 5(19) \\
& 0 \\
& 1(4) \\
& 4(15) \\
& 2(7) \\
& 1(4) \\
& 1(4) \\
& 1(4) \\
& 1(4) \\
& 0 \\
& 0\end{aligned}$ & $\begin{aligned} & 4(7) \\
& 10(18) \\
& 31(54) \\
& 12(21) \\
& 0 \\
& 2(4) \\
& 6(11) \\
& 4(7) \\
& 4(7) \\
& 2(4) \\
& 4(7) \\
& 1(2) \\
& 0 \\
& 0\end{aligned}$ & $\begin{array}{c}20(9) \\
55(25) \\
59(27) \\
72(33) \\
6(3) \\
7(3) \\
24(11) \\
22(10) \\
19(9) \\
38(18) \\
6(3) \\
5(2) \\
3(1) \\
17(8)\end{array}$ \\
\hline
\end{tabular}

TABLE II-Calculation of corrected $P$ values for $H L A-B 8$ in patients with polymyalgia rheumatica $(P M R)$ and temporal arteritis $(T A)$

\begin{tabular}{|c|c|c|c|c|c|c|}
\hline $\begin{array}{l}\text { HLA- } \\
\text { A10 }\end{array}$ & $\underset{\chi^{2}}{\text { Ordinary }}$ & $\mathbf{P}$ & $P \times 22$ & $\begin{array}{c}\text { Yates's } \\
\chi^{2}\end{array}$ & $\mathbf{P}$ & $P \times 22$ \\
\hline $\begin{array}{l}\text { B8 in } \\
\text { PMR } \\
\text { B8 in TA } \\
\text { B8 in }\end{array}$ & $\begin{array}{r}11.48 \\
6.45\end{array}$ & $\begin{array}{l}0.00699 \\
0.0111\end{array}$ & $\begin{array}{l}0.015 \\
0.244\end{array}$ & $\begin{array}{r}10 \cdot 02 \\
5.41\end{array}$ & $\begin{array}{l}0.00152 \\
0.0198\end{array}$ & $\begin{array}{l}0.034 \\
0.4356\end{array}$ \\
\hline $\begin{array}{c}\text { PMR } \\
\text { and TA } \\
\text { A } 10 \text { in }\end{array}$ & $14 \cdot 96$ & 0.00011 & 0.0024 & 13.75 & 0.0021 & $0 \cdot 0046$ \\
\hline $\begin{array}{l}\text { PMR } \\
\text { A10 in }\end{array}$ & $5 \cdot 66$ & 0.0173 & $0 \cdot 381$ & $4 \cdot 25$ & 0.0394 & 0.867 \\
\hline $\mathrm{TA}$ & 0.28 & NS & NS & NS & NS & NS \\
\hline
\end{tabular}

NS $=$ Not significant the $P$ value was corrected $(P c<0.05)$. An increased prevalence was also noted for BW15 and a decreased prevalence for BW 40 and BW 37 , though there were too few patients to establish statistical significance.

\section{Discussion}

Rosenthal et al ${ }^{12}$ reported an increased prevalence of HLA-B8, $A 10$, and BW16 in 15 patients with polymyalgia rheumatica. Our results support their findings in a larger group of patients and in a group with giant-cell arteritis. Terasaki $e t$ al ${ }^{13}$ however, failed to show an increase in any HLA haplotype in 56 patients with polymyalgia rheumatica, nine of whom had positive temporal artery biopsies.

Several different diseases appear to be associated with HLAB8. Adult coeliac disease and dermatitis herpetiformis are closely related clinically, and both show a highly significant increase in B8. ${ }^{14}{ }^{15}$ In addition, there is an association between B8 and myasthenia gravis, but only in those forms not associated with thymomas. ${ }^{16}$ Associations also exist with thyrotoxicosis, ${ }^{17}$ chronic active hepatitis, ${ }^{18}$ idiopathic Addison's disease, ${ }^{19}$ insulin-dependent diabetes mellitus, ${ }^{20}$ and Sjögren's syndrome. ${ }^{21}$ Because B8 is the only HLA antigen occurring with high frequency in several suspected autoimmune diseases, it is becoming more probable that a genetic locus in linkage disequilibrium with $\mathrm{B} 8$ might predispose to these disorders. ${ }^{21}$

A high incidence of other autoimmune diseases has been noted in patients with giant-cell arteritis, especially thyroid disease. ${ }^{22}$ Von Knorring and Somer ${ }^{23}$ reported a case in which polymyalgia rheumatica developed four years before a malignant lymphoma. Although several studies have shown no association of $\mathrm{B} 8$ with lymphomas, others have shown a prevalence of B8 in Hodgkin's disease. ${ }^{24}$ An increase in HLA-A10 has been reported by several investigators in Hodgkin's disease. ${ }^{25}$ Although there is no reported association with chronic active hepatitis, raised serum alkaline phosphatase values were found in $20 \%$ of patients with polymyalgia rheumatica, ${ }^{26}$ and increased 5-nucleotidase values or mitochondrial antibodies or both were found in $50 \%$ of patients with raised alkaline phosphatase values. Long and James ${ }^{27}$ reported on a liver biopsy that showed portal and intralobular inflammation with focal liver cell necrosis.

The association with HLA-B8 reported here provides further evidence that immunological processes are implicated in the pathogenesis of the two conditions. It has been suggested that giant-cell arteritis may arise as an immune reaction to the internal elastic lamina that has been damaged by advancing age. ${ }^{9}$ Certainly a widespread vasculitis would explain many of the features of polymyalgia rheumatica. Hunder et $a l^{11}$ found arteritis in $50 \%$ of temporal biopsies, and Fauchald et $a l^{28}$ found arteritis in 20 temporal biopsies from 49 patients who had myalgia alone.

Our findings provide further evidence that polymyalgia rheumatica and giant-cell arteritis are closely related. Several patients will be classified as cases of polymyalgia rheumatica until biopsy shows arteritis. Conversely, diagnosis based on temporal artery biopsy is not satisfactory because of the segmental distribution of the arteritis and the small section of artery that is examined histologically. Whether these are the same diseases in all cases is uncertain, but it is difficult to maintain a practical distinction between them.

We thank Dr J Darnborough for HLA typing facilities, the physicians at Addenbrooke's Hospital for allowing us to study their patients, and the Arthritis and Rheumatism Council for continuing support.

Requests for reprints should be addressed to: Dr B L Hazleman, Addenbrooke's Hospital, Hills Road, Cambridge CB2 2QQ.

\section{References}

1 Barber, H S, Annals of the Rheumatic Diseases, 1957, 16, 230.

${ }^{2}$ Hamrin, B, Acta Medica Scandinavica, 1972, suppl No 533, p 62. 
${ }^{3}$ Wadman, B, and Werner, I, Acta Medica Scandinavica, 1972, 192, 377.

${ }^{4}$ Liang, G C, et al, Arthritis and Rheumatism, 1974, 17, 19.

${ }_{5}^{5}$ Bell, W R, and Klinefelter, H F, fohns Hopkins Medical fournal, 1967, $121,175$.

${ }^{6}$ Liang, G C, and Simkin. P A, Lancet, 1973, 16, 551.

7 Parker, F, Healey, L A W, and Wilske, K K, Arthritis and Rheumatism, $1972,15,449$.

${ }^{8}$ Bacon, P A, Doherty, S M, and Zuckerman, A J, Lancet, 1975, 2, 476.

${ }^{9}$ Hazleman, B L, MacLennan, I C M, and Esiri, M M, Annals of the Rheumatic Diseases, 1975, 1, 1.

1" Dixon, A St J, Fournal of the Royal College of Physicians of London, 1969-70, 4, 55.

1 Hunder, G G, Disney, T F, and Ward, L E, Mayo Clinic Proceedings, $1969, \mathbf{4 4}, 849$.

${ }^{12}$ Rosenthal, M, et al, New England fournal of Medicine, 1975, 292, 595.

13 Terasaki, P I, Healey, L A, and Wilske, K R, New England fournal of Medicine, 1976, 295, 905.

${ }^{14}$ Falchuk, Z M, Rogentine, G N, and Strober, W, fournal of Clinical Investigation, 1972, 51, 1602.

${ }^{15} \mathrm{Katz}, \mathrm{S} \mathrm{I}$, et al, fournal of Clinical Investigation, 1972, 51, 2977.
${ }^{16}$ Fritze, D, et al, Lancet, 1974, 1, 240.

17 Grumet, F C, Payne, R O, and Konishi, J, fournal of Clinical Endocrinology and Metabolism, 1974, 39, 1115.

${ }^{1 *}$ Mackay, I R, and Morris, R J, Lancet, 1972, 2, 793.

19 Platz, P, et al, Lancet, 1974, 2, 289.

20 Singal, D P, and Blajchman, M A, Diabetes, 1973, 22, 429.

${ }^{21}$ Fye, $\mathrm{K} \mathrm{H}$, et al, Arthritis and Rheumatism, 1976, 19, 883.

${ }^{22}$ Thomas, R D, and Croft, N D, British Medical fournal, 1974, 2, 408.

${ }^{23}$ Von Knorring, J, and Somer, T, Scandinavian fournal of Rheumatology, $1974,3,129$.

24 Dausset, J, Degos, L, and Hors, J, Clinical Immunology and Immunopathology, 1974, 3, 127.

${ }^{25}$ Lawler, S D, and Klouda, P T, Histocompatibility Testing, p 555. Copenhagen, Munksgaard, 1972.

${ }^{26}$ Glick, E N, Lancet, 1974, 1, 77.

27 Long, R, and James, O, Lancet, 1974, 1, 77.

${ }^{28}$ Fauchald, P, Rygvold, O, and Oystese, B, Annals of Internal Medicine, $1972,77,845$.

(Accepted 17 August 1977)

\title{
Bacteriological study of otogenic cerebral abscesses: chemotherapeutic role of metronidazole
}

\author{
H R INGHAM, J B SELKON, C M ROXBY
}

British Medical fournal, 1977, 2, 991-993

\begin{abstract}
Summary
In nine consecutive patients with otogenic cerebral abscesses a mixed growth of aerobic and obligate anaerobic bacteria was isolated from the pus in five patients, and in the remaining four obligate anaerobes were the sole isolates. The commonest obligate anaerobe isolated was Bacteroides fragilis, which was present in all but one patient. The patients were all treated with metronidazole for the anaerobic organisms and with appropriate chemotherapy against the aerobic organisms isolated. All the patients recovered and only one was left with a neurological deficit.

As otogenic cerebral abscesses constitute a major proportion of all cerebral abscesses, the use of metronidazole against obligate anaerobic bacteria, which tend to dominate in such abscesses, should reduce the high mortality from this condition.
\end{abstract}

\section{Introduction}

The bacterial flora of cerebral abscesses secondary to chronic infections of the middle ear is usually complex, consisting of a mixture of aerobes and obligate anaerobes. ${ }^{12}$ In the past penicillin has been recommended as the chemotherapeutic agent of choice in such infections, ${ }^{3}$ but its use, often in very high doses, has been accompanied by high mortality rates. ${ }^{2}{ }^{3}$ This is probably due to the frequent presence in such abscesses of Bacteroides fragilis, an obligate anaerobe which is usually highly resistant

Department of Microbiology, Newcastle General Hospital, Newcastle upon Tyne NE4 6BE

H R INGHAM, MRCPATH, DIP BACT, consultant microbiologist

J B SELKON, FRCPATH, DCP, consultant microbiologist

$\mathrm{C} M$ ROXBY, MB, BS, senior registrar in microbiology to penicillin by virtue of drug tolerance and the production of 3-lactamase. ${ }^{45}$

Other agents that have been used for treating cerebral abscesses, such as chloramphenicol and lincomycin, have not always eradicated the infection ${ }^{2} \mathbf{6}$ and are potentially toxic, especially when administered for the long periods that have been traditional in the chemotherapy of these infections. Recently metronidazole has been used to treat the anaerobic bacterial component of this type of cerebral abscess in a few patients. ${ }^{7-9} \mathrm{We}$ describe here the bacteriological findings in nine patients with otogenic cerebral abscesses and the response to treatment with metronidazole.

\section{Patients and methods}

Ten patients were admitted consecutively to the Newcastle regional neurosurgical unit and diagnosed as having an intracranial abscess secondary to chronic middle ear infection. The diagnosis was confirmed and the lesion localised by angiography, ventriculography, and latterly by computerised axial tomography. One patient (case 6) was dead on arrival, having had a cardiac arrest in the ambulance. The remaining nine patients were treated by surgical aspiration of the abscess and in seven cases by the instillation of antibiotics (table I) into the abscess cavity. All the patients were initially treated with metronidazole 400 to $600 \mathrm{mg} 8$ hourly, orally or intravenously, and penicillin $0.6 \mathrm{~g} 6$ hourly or ampicillin $0.5 \mathrm{~g} 6$ hourly and gentamicin $80 \mathrm{mg} 8$ hourly, the regimen being subsequently modified according to the bacterial flora found in the abscess.

\section{BACTERIOLOGY}

Specimens of pus obtained at surgery were inoculated on to $5 \%$ horse blood agar, which was incubated at $37^{\circ} \mathrm{C}$ aerobically for 48 hours and anaerobically for at least 5 days in an atmosphere of $90 \%$ hydrogen and $10 \%$ carbon dioxide in an anaerobic jar fitted with a cold catalyst. In addition, anaerobic cultures were also carried out on horse blood agar containing nalidixic acid at a final concentration of $50 \mu \mathrm{g} / \mathrm{ml}$ to inhibit selectively Gram-negative aerobes. All isolates growing anaerobically were subcultured aerobically and those failing to grow were further examined to determine their sensitivity to metronidazole 